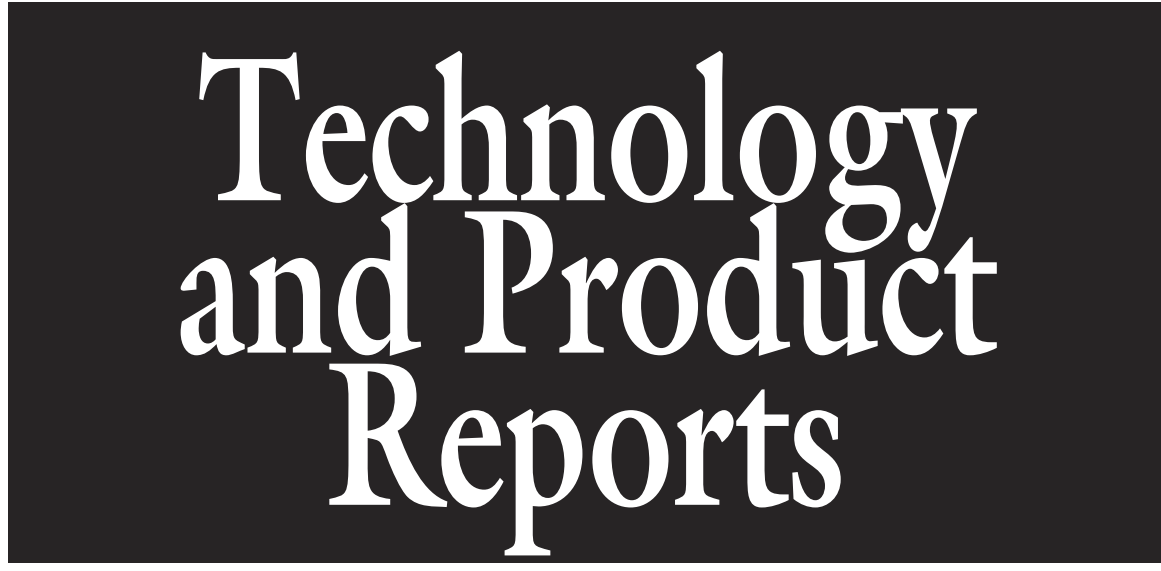

\section{Fuel Type and Releasing the Heated Air Near Plant Roots Reduced Production Cost of Greenhouse Tomatoes}

\author{
Hanna Y. Hanna ${ }^{1}$ and Kenneth D. Henderson
}

ADDITIONAL INDEX wORDS. Lycopersicon esculentum, Solanum lycopersicum, interplant bottom heating system, above-plant heating system, root-media temperature

Summary. A study was conducted to determine the effects of a constructed interplant bottom heating system using diesel fuel and an above-plant heating system using natural gas on heating and production cost of greenhouse tomatoes (Solanum lycopersicum). Two identical greenhouses $30 \times 96 \mathrm{ft}$ were used for this study in the spring (January to July) of 2002 and 2003. The interplant bottom-heated greenhouse consumed an average of $195,790,000 \mathrm{btu}$ during the heating period (January to March) to raise the air temperature $5 \mathrm{ft}$ above the floor to the optimum level for greenhouse tomato production. The above-plant-heated greenhouse consumed an average of $208,100,000 \mathrm{btu}$ to do the same. Using the interplant bottom heating system reduced energy consumption by $6 \%$. Average cost was $\$ 6.22$ and $\$ 9.10$ per million btu from diesel fuel and natural gas, respectively. The difference is $\approx \mathbf{3 2} \%$ reduction in fuel cost based on fuel type. The interplant bottom heating system raised root-media temperature to near the optimum level for tomato growth and increased total yield by $9.5 \%$. Producing $1 \mathrm{lb}$ of tomatoes in the interplant bottomheated greenhouse required 13,266 btu at a heating cost of \$0.08; however, it required $15,459 \mathrm{btu}$ in the above-plant-heated greenhouse at a heating cost of $\$ 0.14$. Less energy, cost-effective fuel, and increased yield reduced heating cost per production unit by $43 \%$ in the interplant bottom-heated greenhouse.

W orldwide energy consumption is greater now than any time in the past, leading to higher fuel prices and costly

Louisiana State University Agricultural Center, Red River Research Station, P.O. Box 8550, Bossier City, LA 71113

Approved for publication by the director of the Louisiana Agricultural Experiment Station as manuscript no. 06-60-0318.

Mention of trademark, proprietary product, or vendor does not constitute a guarantee or warranty of the product by the Louisiana State University Agricultural Center and does not imply its approval to the exclusion of other product or vendor that also may be suitable. ${ }^{1}$ Corresponding author. E-mail: hhanna@agcenter. lsu.edu. greenhouse production. This trend is expected to continue because of the increasing population and improving living standards (Engindeniz, 2005).
Energy cost is the second largest expense for greenhouse tomato production behind labor, and greenhouse heating consumes $70 \%$ to $80 \%$ of the total energy budget (Sanford, 2005).

The U.S. greenhouse tomato industry is a mix of many relatively small, family-operated businesses and a small number of larger (Snyder, 1995). Smaller producers have an excellent opportunity to do well because they do not have to ship the produce to distant markets and absorb the rising cost of transportation. Tomato fruit can be harvested at peak quality and sold to the consumer on the day of harvest at farmers' markets, roadside stands, local supermarkets, or on the producer's premises. However, producers have to reduce production cost and increase plant yield to compete in a market dominated by more efficient, larger producers.

It is a common practice to heat small greenhouse tomato operations in the southern United States with hot air from suspended heaters. Giacomelli (1995) indicated that the hot air system is the simplest and least expensive way to heat greenhouse tomatoes. Furnaces that generate hot air are suspended as high as $10 \mathrm{ft}$ above the greenhouse floor to keep them out of the workplace and blow the heated air above plants. More heat has to be generated to ensure adequate warming at plant level. Even with more generated heat, rootmedia temperature remains less than optimum for plant growth and yield (Hanna and Henderson, 2002).

Natural gas, propane, and diesel are common fuels for heating greenhouse tomatoes. Using natural gas would restrict greenhouse tomato growers to locate their business near a network of underground supply lines or extend a costly supply line to their greenhouse location. Propane is a gaseous fuel much like natural gas

\begin{tabular}{llll}
\hline $\begin{array}{l}\text { Units } \\
\begin{array}{l}\text { To convert U.S. to SI, } \\
\text { multiply by }\end{array}\end{array}$ & U.S. unit & SI unit & $\begin{array}{l}\text { To convert SI to U.S., } \\
\text { multiply by }\end{array}$ \\
\hline 1.0551 & $\mathrm{btu}$ & $\mathrm{kJ}$ & 0.9478 \\
0.3048 & $\mathrm{ft}$ & $\mathrm{m}$ & 3.2808 \\
0.0283 & $\mathrm{ft}^{3}$ & $\mathrm{~m}^{3}$ & 35.3147 \\
3.7854 & gal & $\mathrm{L}$ & 0.2642 \\
2.54 & inch(es) & $\mathrm{cm}$ & 0.3937 \\
0.4536 & $\mathrm{lb}$ & $\mathrm{kg}$ & 2.2046 \\
0.0254 & $\mathrm{mil}$ & $\mathrm{mm}$ & 39.3701 \\
$\left({ }^{\circ} \mathrm{F}-32\right) \div 1.8$ & ${ }^{\circ} \mathrm{F}$ & ${ }^{\circ} \mathrm{C}$ & $\left(1.8 \times{ }^{\circ} \mathrm{C}\right)+32$
\end{tabular}


but has to be stored in liquid form. Although more expensive than natural gas, it can be readily obtained where natural gas is not available (Bartok, 2005). Energy content per gallon of propane is lower than equivalent units of other fuels (Fowler et al., 1997). Acquiring diesel fuel is convenient because it is transported by trucks and farm fuel users may be entitled to some tax benefits by using dyed diesel to heat their greenhouses (U.S. Internal Revenue Service, 2007). Both road and farm diesel are the same, but a red-colored stain is used to mark farm diesel for easy detection if used for other purposes.

Favorable plant response to warm root-media temperature has been well documented. (Bhella, 1988; Gent and Ma, 1998; Gosselin and Trudel, 1983; Trudel and Gosselin, 1982; Wai and Newman, 1992). Sanford (2006) recommended using in-floor or under-bench heating to save energy but indicated that heated floors may not be able to keep up with peak greenhouse heat losses on cold nights.

We constructed an interplant bottom heating system using diesel fuel to deliver the heated air as close as possible to the root-media and allow the warm air to rise through the plant canopy for maximum efficiency. This system was compared with an aboveplant heating system using natural gas. The present study was conducted to address efficient greenhouse tomato production and specifically to determine if fuel cost and releasing the heated air near plant roots would affect energy consumption and tomato production cost.

\section{Material and methods}

Studies were conducted in two identical $30 \times 96$-ft greenhouses covered with double-polyethylene typically used to raise 640 tomato plants each in 320 polyethylene 5 -gal grow bags at the Louisiana State University Agricultural Center in Bossier City. The 320 grow bags were arranged in five double rows of 32 bags with 30 inches between these rows. The double rows were on 5 - $\mathrm{ft}$ centers. This arrangement resulted in $\approx 8$ inches of space between grow bags within each double row. One greenhouse was heated with the above-plant heating system and the other was heated with the interplant bottom heating system.
The above-plant-heated greenhouse was equipped with two propeller-type, gas-fired heaters of 200,000 btu/h total output capacity (Modine Manufacturing, St. Louis). The heaters were suspended $10.5 \mathrm{ft}$ above the floor on the frame of the greenhouse to blow the heated air above the plant (Fig. 1). The fan jet between the two heaters was equipped with a 30 -inchdiameter convection tube with 3 -inch standard-sized holes punched at $30^{\circ}$ down-throw and positioned at 4 and 8 o'clock for proper distribution of the heated air.

The interplant bottom-heated greenhouse was equipped with a diesel-fired, floor-mounted heater having $157,000 \mathrm{btu} / \mathrm{h}$ output heating capacity (SunDair; Sunderman Manufacturing Co., Baltic, SD). This heater was fitted with a homemade wood duct measuring $30 \mathrm{ft}$ long, 18 inches wide, and 18 inches high. The duct was placed next to one end across the width of the greenhouse to transport the heated air. Five 8inch-diameter outlet holes were drilled $5 \mathrm{ft}$ apart on the side of the duct facing the plants to release the heated air. Each hole was connected to an 80-ft-long, 8-inch-diameter, 6-mil polyethylene (convection) tube (Fig. 2). Each tube was placed in the 8 -in space between the two rows of each double row of grow bags after punching holes to release the heated air directly at the sides of the grow bags (Fig. 3). Holes of 1 -inch diameter were punched every 30 inches at the 3 and 9 o'clock locations of the convection tubes to match grow bag location and allow the heated air to exit facing the bags and rise through the plant canopy.

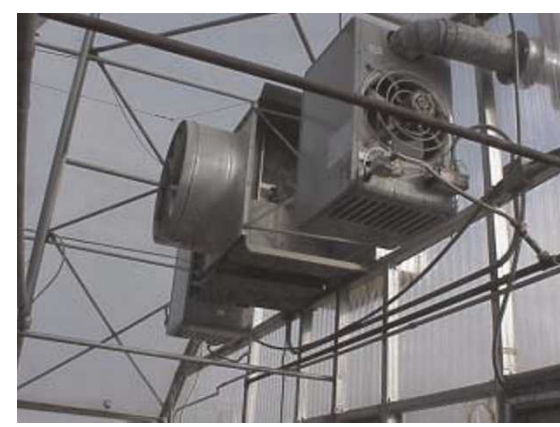

Fig. 1. Two heaters suspended at 10.5 $\mathrm{ft}(3.20 \mathrm{~m})$ above the ground on the frame of the greenhouse to blow the heated air above plant tops.
Heating each greenhouse was controlled by a Wadsworth Control System (STEP 50A; Wadsworth Control System, Arvada, CO). The aspirator modules containing the sensors that provide temperature data from the greenhouse environment to the control system were suspended $5 \mathrm{ft}$ above the floor in the center of each greenhouse. The control systems were set to allow for $75 / 65^{\circ} \mathrm{F}$ maximum/ minimum temperature. Thermometers (Taylor Precision Products, Oak Brook, IL) were suspended next to the aspirators in each greenhouse to record daily maximum/minimum temperatures during the heating period (January to March) in 2002 and 2003. Most of the heating was needed at night and early morning except for a few cold days that required heating throughout the day.

Studies were conducted in the spring (January to July) of 2002 and 2003. In both studies, tomato plants were grown in the 5-gal grow bags filled with perlite. 'Trust' tomato

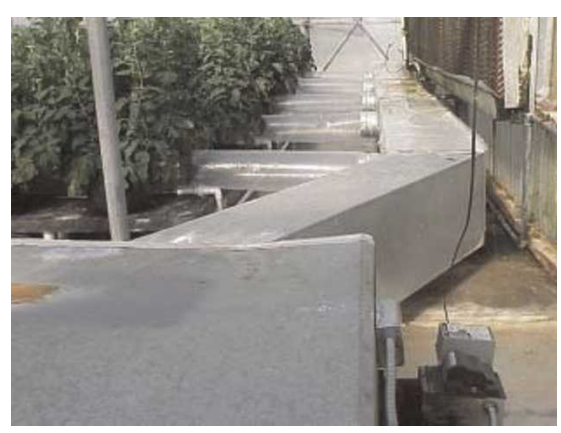

Fig. 2. A floor-mounted heater fitted with a wood duct and five convection tubes to transport the heated air to target areas.

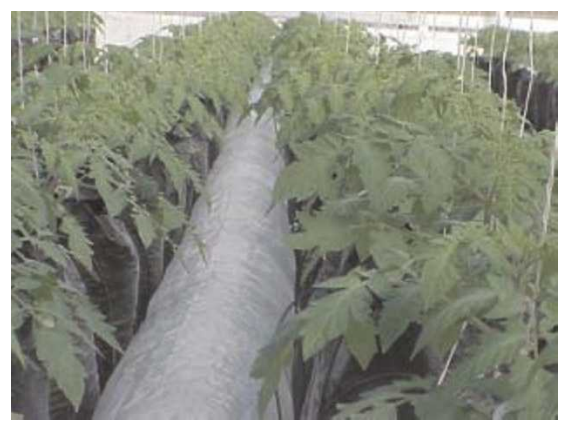

Fig. 3. One of the five convection tubes with punched holes placed in the 8 -inch $(20.3 \mathrm{~cm})$ space between the two rows of each double row to release the heated air at the grow bag side. 
seeds were sown in growing trays (No. 38; Growing Systems, Milwaukee, WI) and transplants were raised in the soilless mix (Pro-Mix BX; Premier Horticulture, Quakertown, PA) for 5 weeks before being planted in the grow bags. Two transplants spaced at 7 inches apart were planted in each bag at a 3-inch depth. Other cultural practices were standard recommendations for growing greenhouse tomatoes (Snyder, 2001).

The temperature of the heated air in the interplant bottom-heated greenhouse was recorded as air exited the convection tube holes at three locations. One location was near the heater, the second was at the greenhouse center, and the third was at the farthest location of the heater. The temperature probe of an 11.5-inch traceable thermometer (model 8922; Mannix Testing and Measurement, New York, NY) was pointed at the convection tube hole until the reading stabilized. In the top-heated greenhouse with no convection tubes between the grow bags, air temperature was recorded in the valley between the grow bags at comparable locations. All temperatures were recorded daily $\approx 0730 \mathrm{HR}$ in both greenhouses during the heating period and the average daily temperature for the three locations was calculated.

Perlite temperature was recorded for the same period of time as previously mentioned in both greenhouses using the same model thermometer. Thermometer probes were inserted 5 inches deep in the perlite bags located at the three mentioned locations in each greenhouse. They were left in place for the duration of the heating period and

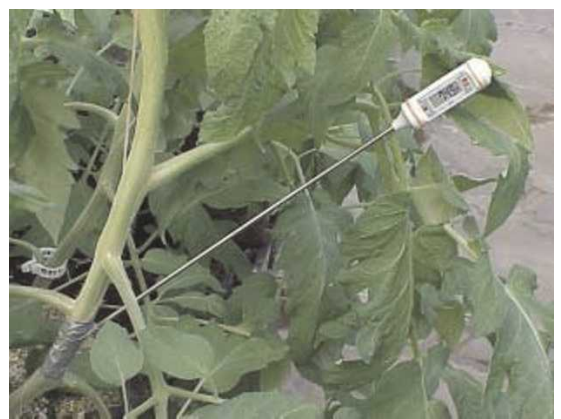

Fig. 4. A long-stem thermometer placed in the tomato stem to measure stem temperature at 8 inches $(20.3 \mathrm{~cm})$ above the plant base. temperature readings were recorded $\approx 0730$ HR daily. The thermometers were turned on for a few seconds for the digital display to stabilize and average daily perlite temperature for the three locations was calculated.

Plant stem temperatures were recorded at the three locations as mentioned previously and the average was calculated during the heating period. This was accomplished by placing the probe of the thermometer inside the plant stem at 8 inches above the plant base. Each thermometer was duct-taped in place for the duration of the heating period (Fig. 4).

Temperatures at the leaf surface were recorded by placing the probe of a carry-on thermometer (same brand) over the leaf blade, 8 inches above the grow bags at the same mentioned locations, and the average temperature was calculated.

All 640 tomato plants were harvested from each greenhouse at the pink stage three times per week for 19 and 20 weeks in 2002 and 2003, respectively. The harvested tomatoes were weighed before being removed from the greenhouse and average production per year for each greenhouse was calculated. Heated air, perlite, plant stem, and leaf surface temperatures and yield were compared for the two heating systems using $t$ test statistic (Steel and Torrie, 1960)

\section{Results and discussion}

Average maximum/minimum daily air temperatures January through March in 2 years at $5 \mathrm{ft}$ above the floor in the center of the greenhouse for the interplant-heated and above-plant-heated greenhouses were
78.1/64.3 ${ }^{\circ} \mathrm{F}$ and $77.8 / 63.8{ }^{\circ} \mathrm{F}$, respectively (Table 1 ). These data indicate that the interplant bottom heating system raised air temperature at the mentioned locations to comparable temperatures raised by the above-plant heating system. Data also indicate that the two systems provided the recommended heat for growing greenhouse tomatoes (Snyder, 2001).

Air released from the convection tubes in the interplant bottom-heated greenhouse had a significantly higher average temperature $\left(99.5^{\circ} \mathrm{F}\right)$ than air drawn down from the above-plant heating system $\left(66.4^{\circ} \mathrm{F}\right)$. The interplant heating system significantly raised perlite temperature to $72.8^{\circ} \mathrm{F}$ over the above-plant heating system, which raised perlite temperature to $65.3{ }^{\circ} \mathrm{F}$. Plant-stem and leaf surface temperatures responded similarly to heating method (Table 1). Papadopoulos and Tiessen (1983) indicated that a root temperature of $75^{\circ} \mathrm{F}$ was optimum for greenhouse tomato production.

The interplant bottom-heated greenhouse consumed a total of $195,790,000$ btu during the heating period to raise the air temperature $5 \mathrm{ft}$ above the floor to the optimum level for greenhouse tomato production. The above-plant-heated greenhouse consumed a total of 208,100,000 btu to do the same (Table 2). These data indicate that the interplant bottom heating system reduced energy consumption by $6 \%$. Average cost from diesel fuel and natural gas was $\$ 6.22$ and $\$ 9.10$ per million btu, respectively (Table 2). This difference is $\approx 32 \%$ reduction in fuel cost based on fuel type. Energy reduction and

Table 1. Average daily temperature in the interplant bottom and above-plantheated greenhouses used for tomato production in 2 years.

Temperature $\left({ }^{\circ} \mathbf{F}\right)^{\mathrm{z}}$

\begin{tabular}{|c|c|c|c|c|c|c|}
\hline \multirow[b]{2}{*}{ Heat } & \multicolumn{2}{|c|}{$\begin{array}{c}\text { At the } \\
\text { aspirator }^{y}\end{array}$} & \multirow{2}{*}{$\begin{array}{l}\text { At grow } \\
\text { bags }^{x}\end{array}$} & \multirow{2}{*}{$\underset{\text { perlite }^{\text {In }}}{\operatorname{In}}$} & \multirow{2}{*}{$\begin{array}{c}\text { In } \\
\text { stem }^{v}\end{array}$} & \multirow{2}{*}{$\begin{array}{l}\text { At leaf } \\
\text { surface }\end{array}$} \\
\hline & Max & Min & & & & \\
\hline Bottom & 78.1 & 64.3 & 99.5 & 72.8 & 67.5 & 70.2 \\
\hline Top & 77.8 & 63.8 & 66.4 & 65.3 & 64.7 & 66.3 \\
\hline Significance & NS & NS & * & * & * & * \\
\hline
\end{tabular}

${ }^{\mathrm{z}}$ Temperature was recorded daily $\approx 0730 \mathrm{HR}$ (January to March) in 2002 and $2003 ;\left({ }^{\circ} \mathrm{F}-32\right) \div 1.8={ }^{\circ} \mathrm{C}$.

${ }^{y}$ Maximum and minimum air temperature were recorded at $5 \mathrm{ft}(1.5 \mathrm{~m})$ above the floor at aspirator location in the center of the greenhouse.

${ }^{x}$ Air temperature at the convection tube opening facing the grow bags in the interplant bottom-heated greenhouse and in the valley between bags in the above-plant-heated greenhouse.

"Perlite temperature at $\approx 5$ inches $(12.7 \mathrm{~cm})$ depth from the surface.

"Inside plant stem temperature at $\approx 8$ inches $(20.3 \mathrm{~cm})$ above the plant base.

"Temperature at leaf surface $\approx 8$ inches above the plant base.

Ns, $*$ Nonsignificant or significant at $P \leq 0.05$ by $t$ test. 
Table 2. Fuel consumption and heating cost of a $30 \times 96-\mathrm{ft}(9.1 \times 29.3 \mathrm{~m})$ greenhouse using two heating systems in 2 years.

\begin{tabular}{|c|c|c|c|c|c|c|c|}
\hline \multirow[b]{2}{*}{ Yr } & \multicolumn{3}{|c|}{$\begin{array}{l}\text { Interplant bottom } \\
\text { heating system }\end{array}$} & \multicolumn{3}{|c|}{$\begin{array}{c}\text { Above-plant heating } \\
\text { system }\end{array}$} & \multirow[b]{2}{*}{$\begin{array}{c}\text { Saving } \\
(\%) \\
\end{array}$} \\
\hline & $\begin{array}{c}\text { Diesel } \\
(\text { gal })^{z}\end{array}$ & $\begin{array}{c}\text { Energy } \\
\text { generated } \\
(\text { btu })^{\mathrm{y}}\end{array}$ & $\begin{array}{c}\text { Cost } \\
(\$ / \text { million } \\
\text { btu })^{y}\end{array}$ & $\begin{array}{c}\begin{array}{c}\text { Natural } \\
\text { gas }\end{array} \\
\left(100 \mathrm{ft}^{3}\right)^{\mathrm{x}} \\
\end{array}$ & $\begin{array}{c}\text { Energy } \\
\text { generated } \\
\text { (btu) }\end{array}$ & $\begin{array}{c}\text { Cost } \\
(\$ / \text { million } \\
\text { btu })\end{array}$ & \\
\hline 2002 & 1,470 & $205,800,000^{\mathrm{w}}$ & 4.57 & 1,931 & $193,100,000^{\mathrm{w}}$ & 8.40 & 42 \\
\hline 2003 & 1,327 & $185,780,000$ & 7.86 & 2,231 & $223,100,000$ & 9.80 & 33 \\
\hline Avg & 1,399 & $195,790,000$ & 6.22 & 2,081 & $208,100,000$ & 9.10 & 38 \\
\hline
\end{tabular}

${ }^{\mathrm{z}} 1 \mathrm{gal}=3.7854 \mathrm{~L} ;$ diesel prices were $\$ 0.64 / \mathrm{gal}$ and $\$ 1.10 / \mathrm{gal}(\$ 1.00 / \mathrm{gal}=\$ 0.2642 / \mathrm{L})$ in 2002 and 2003 , respectively.

y $1 \mathrm{btu}=1.0551 \mathrm{~kJ}, \$ 1.00 /$ million btu $=\$ 0.9478 /$ million $\mathrm{kJ}$.

${ }^{x} 100 \mathrm{ft}^{3}=2.8317 \mathrm{~m}^{3}$; natural gas prices were $\$ 0.84 / 100 \mathrm{ft}^{3}$ and $\$ 0.98 / 100 \mathrm{ft}^{3}\left(\$ 1.00 / 100 \mathrm{ft}^{3}=\$ 0.3531 / \mathrm{m}^{3}\right)$ in 2002 and $_{2003}$, respectively.

${ }^{\mathrm{w}}$ Assumes that each gallon of diesel generates $140,000 \mathrm{btu}$ and each $100 \mathrm{ft}^{3}$ of natural gas generates $100,000 \mathrm{btu}$.

Table 3. Effects of interplant bottom and above-plant-heating systems on tomato yield, heat consumption, and heat cost per unit of production in 2 years.

\begin{tabular}{|c|c|c|c|c|c|c|c|}
\hline \multirow[b]{2}{*}{$\underline{\mathrm{Yr}}$} & \multicolumn{2}{|c|}{$\begin{array}{c}\text { Yield per } \\
\text { greenhouse }(1 \mathrm{~b})^{\mathrm{z}}\end{array}$} & \multicolumn{2}{|c|}{ 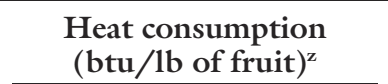 } & \multicolumn{2}{|c|}{$\begin{array}{c}\text { Heat cost }(\$ / \text { btu } \\
\text { per pound of fruit })^{\mathrm{z}}\end{array}$} & \multirow[b]{2}{*}{$\begin{array}{c}\text { Saving } \\
(\%)\end{array}$} \\
\hline & $\begin{array}{c}\text { Interplant } \\
\text { bottom }\end{array}$ & $\begin{array}{c}\text { Above } \\
\text { plant }\end{array}$ & $\begin{array}{c}\text { Interplant } \\
\text { bottom }\end{array}$ & $\begin{array}{c}\text { Above } \\
\text { plant }\end{array}$ & $\begin{array}{c}\text { Interplant } \\
\text { bottom }\end{array}$ & $\begin{array}{c}\text { Above } \\
\text { plant }\end{array}$ & \\
\hline 2002 & $15,519^{y}$ & $13,720^{y}$ & 13,261 & 14,074 & 0.06 & 0.12 & 50 \\
\hline 2003 & 14,000 & 13,246 & 13,270 & 16,843 & 0.10 & 0.15 & 33 \\
\hline Avg & $14,760^{x}$ & $13,483^{x}$ & 13,266 & 15,459 & 0.08 & 0.14 & 43 \\
\hline
\end{tabular}

${ }^{\mathrm{z}} \mathrm{l} \mathrm{lb}=0.4536 \mathrm{~kg}, \mathrm{l} \mathrm{btu} / \mathrm{lb}=2.3261 \mathrm{~kJ} / \mathrm{kg}, \$ 1.00 / \mathrm{btu}$ per pound $=\$ 2.0895 / \mathrm{kJ}$ per kilogram.

yAll 640 tomato plants in each greenhouse were harvested at the pink stage three times per week for 19 and 20 weeks in 2002 and 2003 , respectively.

${ }^{x}$ Average yield differences were not statistically significant at $P \leq 0.05$ by $t$ test.

less costly diesel fuel reduced the heating cost in the interplant bottomheated greenhouse by an average of $38 \%$ (Table 2).

The 640 plants produced a yearly average of 14,760 and $13,483 \mathrm{lb}$ of tomatoes in the interplant bottom and above-plant-heated greenhouses, respectively (Table 3 ). There was, however, no statistically significant differences in yield between the heating systems.

Although the yield increase was not statistically significant, it did contribute to lowering production costs. Producing $\mathrm{l} \mathrm{lb}$ of tomatoes in the interplant bottom-heated greenhouse consumed 13,265 btu at a heating cost of $\$ 0.08$ and 15,434 btu in the above-plant-heated greenhouse at a heating cost of $\$ 0.14$ (Table 3). Less energy, cost-effective fuel, and increased yield reduced heating cost per production unit by $43 \%$ in the interplant bottom-heated greenhouse (Table 3). Sanford (2005) reported that moving heating pipes and air distribution systems from overhead to under bench, on floor or in-floor can save $20 \%$ to $25 \%$ in heating cost. Gent and Ma (1998) indicated that heating the root zone with hot water at night significantly increased tomato yield without the need to raise air temperature to the same level.

\section{Conclusion}

Using a diesel-fired, floormounted heater and a well-designed network of convection tubes to transport and release the heated air at target areas was an economical way to heat the greenhouse to the desired level. The released heated air at the grow bag sides raised root-media temperature to near optimum levels for tomato growth and yield. Previous research on warming the root zone of early spring field tomatoes with black mulch and raising root temperature of greenhouse tomatoes to the optimum level indicated similar results. The rising warm air among plants in our test may help the plant canopy by reducing interplant humidity, which can lead to greater disease problems.

The described interplant bottom heating system should be considered by smaller growers because of lower initial cost, simplicity, low heating cost, and cost-effective tomato production. It was less costly to buy and easier to install one heater $(\approx \$ 1000)$ for the interplant bottom-heated greenhouse than buying and installing two heaters $(\approx \$ 2000)$ for the above plant. Growers can use either factory-punched convection tubes or they can buy unpunched tubes and punch them themselves. Most market-ready convection tubes with factory-punched holes are made from 3 - to 4-mil polyethylene. Growers can buy 6-mil polyethylene tubes without punched holes at a lower cost, which last longer. It took us less than two person-hours to punch holes in the tubes for one greenhouse using homemade tools that cost less than $\$ 15$. To punch the holes, growers need a piece of 1 -inch-diameter galvanized pipe with a cap on one end and a sharpened circumference on the other. A rubber mallet is needed to bang on the pipe cap after placing marked locations on the convection tubes between the sharp end of the pipe and a $4 \times 4$-inch piece of wood for support. After the heating season is over, growers can use the same floor-mounted heater as a fan-only system to draw outside air, when temperatures are favorable, and release it at the base of tomato plants for better ventilation.

We used diesel and natural gas as fuels in this study. Other fuels such as propane can be used. However, growers should consider the energy content and price before making a choice.

\section{Literature cited}

Bartok, J.W., Jr. 2005. Fuels and alternate heat sources for commercial greenhouse. 
4 Jan. 2007. <http://www.umass.edu/ umext/floriculture/fact_sheets/green house_management/jb_fuels.html>.

Bhella, H.S. 1988. Tomato response to trickle irrigation and black polyethylene mulch. J. Amer. Soc. Hort. Sci. 113:543-546.

Engindeniz, S. 2005. Geothermal energy an alternative energy source for greenhouse crop production in Turkey. Practical Hydroponics Greenhouses May/ June:41-44.

Fowler, P.A., R.A. Bucklin, C.D. Baird, F.A. Chapman, and C.A. Watson. 1997. Comparison of energy needed to heat greenhouses and insulated frame buildings used in aquaculture. Univ. Florida Coop. Ext. Serv. Circ 1198.

Gent, M.P.N. and Y.-Z. Ma. 1998. Diurnal temperature variation of the root and shoot affects yield of greenhouse tomato. HortScience 33:47-51.

Giacomelli, G.A. 1995. Cooling and heating the greenhouse for control of plant environment, p. 16-20. In: Proceedings of the greenhouse tomato seminar. ASHS Seminar Series. ASHS Press, Alexandria, VA.

Gosselin, A. and M.J. Trudel. 1983. Interactions between air and root temperatures on greenhouse tomato: I. Growth, development, and yield. J. Amer. Soc. Hort. Sci. 108:901-905.

Hanna, H.Y. and K.D. Henderson. 2002. Modifying greenhouse heating systems to reduce energy cost and produce more tomatoes. Louisiana Agr. 45:10-11.

Papadopoulos, A.P. and H. Tiessen. 1983. Root and air temperature effects on the flowering and yield of tomato. J. Amer. Soc. Hort. Sci. 108:805-809.

Sanford, S. 2005. Reducing natural gas/ propane use for greenhouse space heating. Tomato Mag. April:18-21.

Sanford, S. 2006. Greenhouse unit heaters: Types, placement and efficiency. Tomato Mag. June:4-5, 20-21.
Snyder, R.G. 1995. Greenhouse tomatoes-the basics of successful production, p.3-6. In: Proceedings of the greenhouse tomato seminar. ASHS Seminar Series. ASHA Press, Alexandria, VA.

Snyder, R.G. 2001. Greenhouse tomato handbook. Mississippi State Univ. Ext. Serv. Publ. 1828.

Steel, R.G.D. and J.H. Torrie. 1960. Principles and procedures of statistics. McGraw-Hill, New York.

Trudel, M.J. and A. Gosselin. 1982. Influence of soil temperature in greenhouse tomato production. HortScience 17:928-929.

U.S. Internal Revenue Service. 2007. Excise taxes including fuel tax credits and refunds. IRS Publ. 510. Internal Revenue Service, Washington, DC.

Wai, K.S. and S.E. Newman. 1992. Air and root-zone temperatures influence growth and flowering of snapdragons. HortScience 27:796-798. 